\title{
DYNAMICS OF LEARNING MOTIVATION/ DE-MOTIVATION IN THE CONTEXT OF TEACHERS' COMPETENCIES IN LEARNING MOTIVATION
}

\author{
Birutė Anužienè \\ Klaipèda University, Lithuania \\ Rūta Marija Andriekienè \\ Klaipèda University, Lithuania \\ Marina Voropajeva \\ Klaipèda University, Lithuania
}

\begin{abstract}
This article presents findings of the study of students' attitude toward the dynamics of learning motivation/de-motivation and teachers' competencies in learning motivation. The study is based on the assumption that students' motivation in higher education (college or university) is to be supported and enhanced throughout their studies, while positive dynamics of it is subject to the use of learning motivation competencies by teachers in their teaching activities. It is highly important to identify the interrelation between teachers' competencies in learning motivation and students' motivation/de-motivation factors so that to establish tools for refining the objects under study, to enable a purposeful action, to make a focused intervention in the ongoing teaching processes for improvement thereof and obtaining better learning outcomes for students. Analysis of students' attitude might help to respond more comprehensively the following problematic questions: What are motivation/de-motivation factors for student learning? What do teachers' competencies in learning motivation consist of? In what ways can a teacher support the positive dynamics of learning motivation in students? Thus, this article is aimed to analyse factors for the dynamics of students' motivation/de-motivation, a content of teachers' competencies in learning motivation, and their practice from the students' point of view. The article consists of an introduction and two parts: the first part provides theoretical discourse, the second part is dedicated to an empirical analysis of students' attitude toward the learning motivation/de-motivation factors, teachers' competencies in learning motivation, a content thereof, and dynamics of learning motivation. The article ends with a discussion and conclusions, followed by references.
\end{abstract}

Keywords: dynamics of learning motivation, competencies in learning motivation, learning motivation/de-motivation.

\section{Introduction}

Since the sixties of the 20th century, learning motivation has attracted the attention of many scholars in educational psychology, pedagogy, andragogy, and other sciences. As a result, this has generated abundant and diverse scientific 
publications, theories and models of motivation that are available to us today (Bourgeois, 2011). Because learning motivation in the context of higher education is a complex and ambiguous subject of study which involves many variables, the definition proposed by R. Viau (2009) was proposed as most suitable for this research. Motivation in the learning context is defined as "a dynamic state based on the perception that a learner can have of himself and his environment that pushes him to a choice of activity, to engage in it and persevere in accomplishing in order to arrive to the goals" (p.12).

Those who face the reality of academic work day by day realise that not all students have an intrinsic motivation to learn, whereas teachers have little control over external factors of motivation. Many scholars of learning motivation emphasise the complicated nature of this phenomenon. First, this behaviour (lack of motivation in students and inadequate control over factors of motivation by teachers) may have several causes; and secondly, the cause itself may have various behavioural consequences. According to R Viau (2009), a student naturally has an intrinsic motivation to learn, however, it is constantly fluctuating, subject to a number of external factors. Based on this observation, the author places his framework of student motivational dynamics at the centre of factors of external influence grouped into four categories: those related to the personal life of the student, to society, to the school, and to the classroom. Despite the importance of all the above factors, the author (Viau, 2009) believes that classroom-related factors have the greatest influence on the motivational dynamics of students. The above factors make a very close interrelation between students and a teacher, the teacher's control over the classroom, his didactic activities, and assessment of learning outcomes practiced by him (Viau, 2014). The author gives priority to didactic activities for other reasons as well, because it is the basis of classroom life [and] there is no learning without it (Viau, 2009, p.15). So, didactic competencies in higher education evidently become a key tool for enhancing the efficiency of all other areas of activities of teachers, i.e., scientific, practical, curriculum, international, and cultural ones.

In higher education, students' performance in the study process is determined by their motivation to learn, their experience, their confidence in the meaningfulness of the studies, success and capabilities, etc. (Bagdonas et al., 2012, p.80). One of the key prerequisites for the effectiveness of such activities is competent teachers who are able to educate highly qualified specialists to meet the constantly changing labour market requirements, and to assure positive dynamics in students' motivation to learn throughout the studies.

According to J. Matzler et al. (2012, p.494), there is an obvious relationship among teachers' competencies, students' learning outcomes, and motivational dynamics in their learning. Findings of the author's study show that the quality of academic activities is directly linked to students' performance. Therefore, the 
development of competency in learning motivation, which is understood as the ability to influence learners in achieving their goals, becomes a priority requirement for teachers (Viau, 2014, 239). The efficiency of pedagogic work and students' academic activities depends on the teacher's efforts and attitudes, the ability to use motivational tools, the level of motivation of the learners, etc.

The study is based on the assumption that students' learning motivation, in particular, its positive dynamics, in higher education is to be supported and enhanced throughout their studies, while positive dynamics of it is subject to the use of learning motivation competencies by teachers in their teaching activities.

Analysis of students' attitude toward the dynamics of learning motivation/de-motivation in the context of teachers' competencies in learning motivation might help to respond more comprehensively the following problematic questions: What are motivation/de-motivation factors for student learning? What do teachers' competencies in learning motivation consist of? In what ways can a teacher support the positive dynamics of learning motivation in students? Thus, this article is aimed to analyse factors for the dynamics of students' motivation/de-motivation, a content of teachers' competencies in learning motivation, and their practice from the students' point of view.

The novelty and practical relevance of the study is supported by the model of learning motivation dynamics (Viau, 2009), which focuses on more than just the sources of learning motivation, such as a learner's perception of himself and his environment, but also on teaching activities and a teacher's competencies in learning motivation. Since a teacher's didactic activities and competencies in learning motivation are deemed the sources of motivation to learn, the above motivational dynamics model facilitates the analysis of certain elements.

\section{Theoretical Discourse on Learning Motivation Theories and Competencies in Learning Motivation}

In education and academic areas, many modern theoretical models of learning motivation have a long tradition. for example, there is the selfdetermination theory developed by Richard Ryan and Edward Deci (2000) and the expectancy-value theory of Jacquelynne Eccles and Allan Wigfield (2002).

Self-determination theory. The self-determination theory proposed by Ryan and Deci (2000) is based on the notion that a person inherently has a freedom of choice to do an activity. The authors refer to empirical studies, arguing that the quality of experience and performance can be very different when one is behaving for intrinsic versus extrinsic reasons. They propose a theory enabling to distinct between intrinsic and extrinsic motivation in view of the goals that motivate an individual to act. According to Ryan and Deci (2000), intrinsic motivation has emerged as important phenomena for educators and results in high-quality 
learning, creativity, and spontaneous behaviours. Extrinsic motivation is a construct that pertains whenever an activity is done in order to attain some separable outcome, thus, has an instrumental value. According to F. Fenouillet and A. Lieury (2013, p.54), extrinsic motivation is nevertheless a powerful stimulus for learning.

Ryan and Deci (2000) state that external motivation tends to increase over the years. They see it as a consequence of the role and responsibilities of an adult. Conversely, Fenouillet and Lieury (2013) argue that in a learning context, intrinsic motivation differs from extrinsic one by a greater determination (p.81). The authors assume that if a person is not motivated, he or she may be tempted to give up the studies where there is no support or upon failure to achieve an expected result. According to Ryan and Deci (2000), a person is intrinsically motivated when environments provide supports for the needs for: competence, relatedness, and autonomy.

Expectancy-value theory. The theory, developed by J.S. Eccles and A. Wigfield (2002) is undoubtedly one of the most widely used theoretical models of learning motivation. The authors (Eccles \& Wigfield, 2002) were inspired by the work and thesis of Atkinson (1964), including beliefs about ability and expectancies for success, along with incentives for engaging in different activities, including valuing of achievement (Eccles, 2005, p.107). Though some cognitivists (Aktinson, 1957, 1964; Battle, 1966; Eccles, 2005, p.108), engaged in learning motivation studies, pointed out the importance of these two variables as many as several decades ago, this was the model of Eccles and Wigfield (2002), which made a close connection between them. However, value components are more elaborate and are linked to a broader array of psychological and social/cultural determinants. On the other hand, these two factors (expectancies and values) are assumed to be positively related to each other, rather than inversely related, as proposed by Atkinson. Eccles' and Wigfield' (2002) theoretical model was validated through several important study cycles, mainly conducted in the educational context (Bourgeois, 2011). These studies have revealed that a student's choice to learn is determined by the expectancies for success and perceived value, influenced by the student's identity-related constructs, affective memories, ask values, and culturally based stereotypes, that are typically associated with performance.

Model of learning motivation dynamics (Viau, 2009). His theoretical model emphasises dynamics of a student's motivation, as well as specific determinants of the latter, related to pedagogical activity. This theoretical model is based on a socio-cognitivist approach and is inspired by theories of J.S. Eccles and colleagues (Eccles, 2005), D.H. Schunk and F. Pajares (2002), as well as by R.M. Ryan and E.L. Deci (2000). The motivational dynamics model consists of two main components: sources of learning motivation and manifestations thereof. 
Under the socio-cognitivist approach, perception is the main source of personal motivation. In the learning context, the perception of a learner in relation to the didactic activity offered to him or her allows considering his or her individual characteristics (Viau, 2009). The motivational dynamics model suggests that individual characteristics of a student are subject to a threefold perception: 1. Perception of value of pedagogical and learning activity; 2. Perception of self-competency and competency of others; 3. Perception of controllability.

Thus, a student's perception helps to explain how his or her motivation develops and how it affects his or her learning. Perception means the assessment of an individual's, events, others, and self-assessment (Viau, 2009, p.22). It is subjective, interpretive, and varies subject to individual characteristics of each student. Though, perception cannot be wrong as each person has his or her own truth.

In the light of the above, Viau's (2009) motivational dynamics model seems to be a privileged example to analyse how students' motivation changes from the beginning to the end of a study course. Unlike the self-determination theory (Ryan \& Deci, 2000) or the expectancy-value theory (Eccles \& Wigfield, 2002), the motivational dynamics model facilitates an analysis of certain elements, such as sources of learning whereby a teacher's didactic activities and competencies in learning motivation are deemed the sources of motivation to learn, primarily, because of the perception that a learner can have of himself and his environment, as well from his teacher's pedagogic activities. Besides, in view of the interaction between student behaviour, his or her individual characteristics, and environment, Viau's model (2009) tends to avoid conflict between intrinsic and extrinsic motivation.

The teacher, therefore, will be able to keep up learning motivation and promote its positive dynamics once he understands the very process of learning motivation, a mechanism of motivation, and interaction between individual elements of motivation: a student's perception of himself and his environment, learning and didactic behaviour, environmental determinants. On the other hand, the situations, where the student perceives the teacher's didactic and his own learning activities and behaviours as meaningful and useful, the student realises that his and the teacher's knowledge and competencies enable the academic activities to be implemented in an acceptable manner, or the student and the teacher assume full accountability for the didactic and individual academic activities, assure positive dynamics in learning motivation or at least maintenance of its initial level.

Whereas motivation to learn is defined as pushing oneself to a choice of activity, to engage in it and persevere in accomplishing in order to arrive to the goals (Viau, 2014, 239), the student motivation to learn can be assumed to be 
linked to all areas of teaching activities. After all, the teacher has almost no area of activity that would not engage students directly or indirectly.

In order for an individual to have the determination to learn and develop competencies, he or she needs a competency development system for systematisation of existing knowledge and competencies by various means. It is necessary to recognise, therefore, that every adult learner should know why he or she has to learn. What are or will the benefits of his or her learning be? What will his or her social, professional recognition be? Will any of his or her learning activity be recognised as a socially equitable and necessary, useful action? The answers to the above questions form the key elements of motivation of an adult learner, which B. Jatkauskienè (2013, p.174) defines as epistemological incentives for commitment to learn. The author points out, however, that these learning incentives alone do not determine or explain adult learning - they are rather complementary to other things that arise from the learner's interaction with professional, personal, social, and other environments unknown to a frequent teacher or andragogue. The latter, thus, must understand what determines an adult's learning motivation and what his or her expectations and needs are. In cognitive terms, understanding of an adult's learning system helps to better realise a nature of the constructs that control the learning process (Jatkauskiene, 2013, p.178).

A teacher's pedagogic functions have a great influence on students' and teachers' perception of value of their activity, competencies and controllability. As mentioned above, motivation to learn boosts when a student realises that his or her learning and teachers' didactic activities are meaningful, useful, his or her competences allow running his learning activities, improving his existing competencies, and that not only the teacher can control the learning process. It is not enough for the teacher just to know a content of the course so that to keep up students' motivation to learn. Today, the teacher should redefine his or her central role in shaping/reshaping his or her professional identity and in answering the following questions: Who am I to the students: a supervisor, an assistant, facilitator, or an animator? (Bédard, 2014).

\section{Findings of Analysis of an Attitude Toward Learning Motivation/ De-motivation Dynamics and Teachers' Competencies in Learning Motivation}

Study design. In this research, the process of designing, construction, primary data collection and rational choice of analysis methods are described as a study design (Bitinas, 2013).

On the initiative of Klaipeda University, Faculty of Social Sciences and Humanities, Centre for Continuing Studies, Department of Andragogy, a study 
was conducted in 2019 with the aim to find out respondents' attitude toward dynamics of learning motivation/ de-motivation in the context of teachers' competencies in learning motivation. A quantitative approach of the empirical study was selected. The scientific literature was analysed and an empirical study designed. It consists of several stages:

1) preparation for research;

2) survey;

3) data analysis;

4) discussion of findings.

At the first stage, an empirical research tool - closed-ended questions - was developed. It is based on key parameters that were identified during the analysis of scientific literature. The first part of the questionnaire was intended to analyse demographic data; the second part - factors of the respondents' attitude toward learning motivation, and the third part - to analyse an attitude toward learning motivation/ de-motivation dynamics and teachers' competencies in learning motivation. The validity (internal reliability) of the research questionnaire was pursued by means of the expert evaluation method. The purpose of the research and general information on filling the questionnaire was presented to respondents. Respondents' anonymity was ensured, without the need to specify their full name. Statements and questions of the questionnaire were not offensive or degrading.

The second stage involved a survey of students of educology and andragogy study programmes at Klaipeda University, Vytautas Magnus University, and Vilnius University.

The research applied a target criterion selection, i.e., population sample units were selected by the set criteria (students of first and second cycle study programmes in educology and andragogy). This method of selection is justified by the assumption that students in the above programmes have the best understanding of the essence of didactics and learning motivation in higher education, so, their answers to questions of the survey may be significant.

In designing the sample, the survey respondents were intended to represent a general population of students of the first and second cycle programmes in educology and andragogy. In order to estimate a sample size and to summarise results of the study in terms of the general population with a 5\% error, the calculations proposed by B. Bitinas (1998, p.145) were used. Therefore, 198 students were considered to be a sufficient and representative sample of the study. Since feminisation by students' gender prevails in study programmes of educology and andragogy, $87 \%$ of the survey respondents were female. The average age of all participants was 24 years as the study involved not only fulltime students $(64 \%)$ but part-time students $(36 \%)$, too. The majority $(68 \%)$ of them study and work. 
At the third stage, the data obtained were analysed using the statistical database approaches: descriptive statistics, correlation analysis, etc. Analysis of data was carried out using the statistical analysis software for social sciences, SPSS 17.

This article presents only some of the key findings of empirical research based on formulated partial survey questions. To answer these questions, the data from students' questionnaire were analysed. Relationship of findings under this research with other studies is presented in the discussion section.

Research results. Scales of learning motivation / de-motivation factors. The study revealed the factors that determine respondents' motivation (Table 1):

Table 1 A subscale of factors of learning motivation

\begin{tabular}{|lcccc|}
\multicolumn{1}{c}{ Factors of learning motivation } & $\begin{array}{c}\text { Average } \\
\text { rank }\end{array}$ & $\chi^{\mathbf{2}}$ & df & p \\
\hline $\begin{array}{l}\text { Didactic activities of teachers adapted to a specific } \\
\text { group }\end{array}$ & 48.23 & 42.363 & 1 & 0.000 \\
$\begin{array}{l}\text { Objective assessment of student academic } \\
\text { achievements }\end{array}$ & 43.84 & 38.271 & 1 & 0.001 \\
\hline $\begin{array}{l}\text { Positive teacher-student relationships } \\
\text { Favourable learning environment }\end{array}$ & 35.33 & 38.270 & 1 & 0.000 \\
\hline $\begin{array}{l}\text { Incentive scheme applied by the teacher } \\
\text { Other }\end{array}$ & 36.25 & 41.346 & 1 & 0.000 \\
\hline
\end{tabular}

By applying the Kruskal-Wallis criterion, statistically significant results were obtained, with $p<0.05$. The table shows that students allocate highest relevance to: didactic activities of teachers adapted to a specific group (average rank - 48.23; $\chi^{2}-42.363$; df-1; p-000); objective assessment of student academic achievements (average rank - 43.84; $\chi^{2}-38.271$; df-1; p-001); favourable learning environment (average rank - 36.25; $\chi 2$ - 41.346; df-1; $\mathrm{p}-0.000$ ). The student group is heterogenous in various aspects (age, gender, competencies, social status, cultural capital, etc.). Therefore, the ability of the teacher to adapt to the diversity of the group members, creation of a positive and appropriate learning environment, and objective assessment of the students are highly significant for their motivation. Interaction of a competent teacher with students, a transfer of his or her expertise should form the connecting link between generations and serve as a support for young people in shaping their life principles, knowledge system. It is not easy to meet these requirements, in particular, where a "don't care" attitude toward learning is considered normal in a certain faculty or institution, and the learning issues faced by students are not the teacher's problem.

The study established the factors that determine loss of students' motivation (Table 2): 
Proceedings of the International Scientific Conference. Volume I, May $22^{\text {th }}-23^{\text {th }}, 2020.26-44$

Table 2 A subscale of factors of learning de-motivation (loss of motivation)

\begin{tabular}{|c|c|c|c|c|}
\hline Factors of learning de-motivation & $\begin{array}{l}\text { Average } \\
\text { rank }\end{array}$ & $x^{2}$ & df & p \\
\hline $\begin{array}{l}\text { Assignments, a content, requirements are too difficult } \\
\text { and problematic }\end{array}$ & 45.13 & 52.351 & 1 & 0.000 \\
\hline $\begin{array}{l}\text { Negative assessment and negative feedback on } \\
\text { assignments }\end{array}$ & 38.15 & 1.259 & 1 & 0.001 \\
\hline Too strict and demanding teachers & 36.28 & 32.210 & 1 & 0.000 \\
\hline $\begin{array}{l}\text { Lack of teacher's support in learning, addressing } \\
\text { learning issues }\end{array}$ & 40.74 & 44.439 & 1 & 0.000 \\
\hline $\begin{array}{l}\text { Teacher's failure to instruct a subject in an acceptable, } \\
\text { clear and non-boring manner }\end{array}$ & 39.72 & 51.232 & 1 & 0.000 \\
\hline $\begin{array}{l}\text { Disrespect for students' social, cultural, linguistic and / } \\
\text { or ethnic identity }\end{array}$ & 36.26 & 47.329 & 1 & 0.000 \\
\hline Emerging personal, financial, health, other problems & 32.78 & 48.293 & 3 & 0.000 \\
\hline Other & 2 & 52.178 & 1 & 0.001 \\
\hline
\end{tabular}

By applying the Kruskal-Wallis criterion, statistically significant results were obtained, with $p<0.05$. The data presented in the table demonstrate that students' de-motivation (loss of motivation) is determined by: too difficult and problematic assignments, content, requirements of a study subject (average rank $\left.45.13 ; \chi^{2}-52.351 ; \mathrm{df}-1 ; \mathrm{p}-0.000\right)$; lack of teacher's support in learning, addressing learning issues (average rank $-40.74 ; \chi^{2}-44.439 ; \mathrm{df}-1 ; \mathrm{p}-0.000$ ); a teacher's failure to instruct a subject in an acceptable, clear and non-boring manner (average rank - 39.72; $\chi 2-51.232 ; \mathrm{df}-1 ; \mathrm{p}-0.000$ ). The obtained results show that there is no significant difference between the assessments of students of both full-time and part-time studies, with the probability of significance under the Mann-Whitney U test $p>0.05$. The trend in research suggests that students in higher education expect the teachers' respectful behaviour and specific competencies in didactics or andragogy, which are needed to help students with learning issues. The same applies to interestingness and delivery of the didactic content. Therefore, it is believed that the lack of teachers' competencies in didactics or andragogy in higher education initiates the process of learning demotivation. The latter is determined by negative assessment, too strict and demanding teachers, lack of support in addressing learning issues.

Respondents were asked: Can you say that learning motivation is not stable, do you notice its dynamics throughout the studies? Their answers are presented in the figure below: 


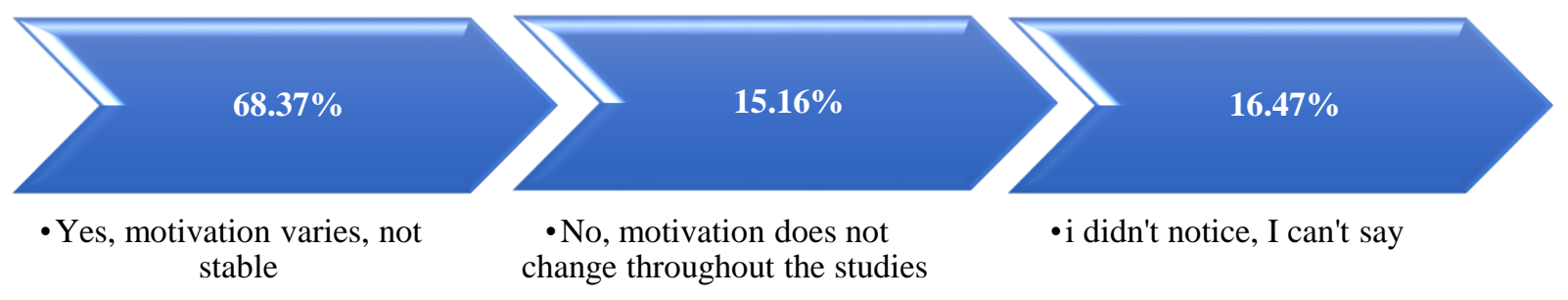

Figure 1 Illustration of learning motivation dynamics

According to the survey data, as many as $68.3 \%$ of survey participants believe that motivation tends to vary because it is unstable or may not be stable. Only $15.16 \%$ think that it remains stable throughout the studies, and $16.47 \%$ of participants could not answer the question as they did not notice it. The obtained results show that there is no significant difference between the assessments of students of both full-time and part-time studies, with the probability of significance under the Mann-Whitney $U$ test $p>0.05$. Learning motivation may go down where there is dissatisfaction with previous learning experiences (Kairys et al., 2017). Results of a study conducted in Lithuanian higher education institutions (Kairys et al., 2017) show that the fluctuation in students' learning motivation is associated with their age and cycle degree. Senior students are more likely to notice efforts of their teachers, willing to discuss learning with them, analyse their progress, study materials, etc. All students find themselves encouraged to work independently and see efforts to motivate the latter through in-depth study programmes.

Scales of competency in learning motivation and motivation support activities. The survey participants were asked to express their agreement / disagreement with each of the competencies in learning motivation and assess each statement on a six-point scale, where 1 - strongly disagree, 2 - disagree, 3 rather disagree than agree, 4 - rather agree than disagree, 5 - agree, 6 - strongly agree (Table 3):

Table 3 Subscale of respondents' agreement / disagreement with competencies in learning motivation (percentage)

\begin{tabular}{|lllllll|}
\hline \multicolumn{1}{|c|}{ STATEMENT } & $\mathbf{1}$ & $\mathbf{2}$ & $\mathbf{3}$ & $\mathbf{4}$ & $\mathbf{5}$ & $\mathbf{6}$ \\
& $\mathbf{\%}$ & $\mathbf{\%}$ & $\mathbf{\%}$ & $\mathbf{\%}$ & $\mathbf{\%}$ & $\mathbf{\%}$ \\
\hline & 0 & 1 & 2 & 10 & 27 & 60 \\
$\begin{array}{l}\text { To be able to give meaning to students' learning (study) and } \\
\text { didactic activities }\end{array}$ & & & & & \\
\hline $\begin{array}{l}\text { To know and apply various didactic methods and techniques to } \\
\text { meet students' needs, competencies, personal characteristics }\end{array}$ & 0 & 1 & 2 & 11 & 28 & 59 \\
\hline To be authentic & 2 & 1 & 3 & 11 & 30 & 52 \\
\hline
\end{tabular}


To be able to engage a student in cognitive activities by sharing $\quad \begin{array}{llllll}0 & 0 & 1 & 9 & 38 & 53\end{array}$ one's own experience, knowledge, his or her search, dissemination, commitment to knowledge, etc.

To be able to provide students with a choice of study subjects, $\quad \begin{array}{llllll}0 & 0 & 1 & 20 & 25 & 54\end{array}$ topics of research work, projects, team, duration of activities, method of presentation, etc.;

To be able to enable students to collaborate and interact with $\quad \begin{array}{llllll}0 & 1 & 3 & 12 & 33 & 51\end{array}$ others by creating the right learning environment

$\begin{array}{llllllll}\text { To adjust didactic activities and study content taking into } & 0 & 1 & 2 & 20 & 28 & 50\end{array}$ account students' skills and knowledge

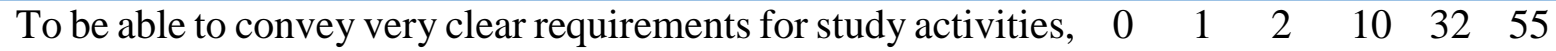
learning outcomes, assessment

To be able to convey lecture content in interdisciplinary $0 \quad \begin{array}{llllll}0 & 1 & 4 & 18 & 26 & 52\end{array}$ perspective

To have time management skills

Other

$\begin{array}{llllll}0 & 1 & 5 & 18 & 28 & 48\end{array}$

$\begin{array}{llllll}0 & 2 & 8 & 24 & 36 & 31\end{array}$

By applying the Kruskal-Wallis criterion, statistically significant results of the respondents' agreement / disagreement with competencies in learning motivation were obtained. Even $60 \%(\chi 2-54.267$, df-2, p $=0.000)$ of study participants stated that teachers' competency in learning motivation consists of the ability to give meaning to students' learning (study) and didactic activities; $59 \%$ of respondents fully agree with the need to know and apply various didactic methods and techniques to meet students' needs, competencies, personal characteristics. $55 \%(\chi 2-46.378, \mathrm{df}-2, \mathrm{p}=0.000)$ of students fully agree with the statement that a teacher must be able to convey very clear requirements for study activities, learning outcomes, assessment. 54\% $(\chi 2-45.185$, df- $2, \mathrm{p}=0.000)$ of all respondents fully agree with the statement that the teacher must be able to provide students with a choice of study subjects, topics of research work, projects, team, duration of activities, method of presentation, etc. This tendency shows that students seek to control their study and learning process at least in part. More than half of the respondents, $53 \%,(\chi 2-48.543, \mathrm{df}-2, \mathrm{p}=0.000)$, believe that a teacher should be able to engage a student in cognitive activities by sharing one's own experience, knowledge, his or her search, dissemination, commitment to knowledge, etc. As already seen, there are lots of components of motivation to learn. The students principally agreed with all of the statements. However, it is much more difficult, as already mentioned, to enhance an in-depth attitude of students toward learning / studies in an effort to engage students in learning activities in a responsible and active manner. That means, students' motivation to learn is integrally associated with a teacher's competencies in didactics in higher education, some of which imply competencies in learning motivation. The obtained results show that there is no significant difference between the 
assessments of students of both full-time and part-time studies, with the probability of significance under the Mann-Whitney U test $\mathrm{p}>0.05$.

In the survey, respondents were asked to express their agreement / disagreement with each of activities of a teacher in maintaining positive learning motivation and its dynamics and to assess each statement on a six-point scale, where 1 - strongly disagree, 2 - disagree, 3 - rather disagree than agree, 4 -rather agree than disagree, 5 - agree, 6 - strongly agree (Table 4 ):

Table 4 Sub-scale of a teacher's activity in maintaining and promoting learning motivation (percentage)

\begin{tabular}{|c|c|c|c|c|c|c|}
\hline STATEMENT & 1 & $\begin{array}{l}2 \\
\%\end{array}$ & $\begin{array}{l}3 \\
\%\end{array}$ & $\begin{array}{l}4 \\
\%\end{array}$ & $\begin{array}{l}5 \\
\%\end{array}$ & $\begin{array}{l}6 \\
\%\end{array}$ \\
\hline Presentation of curriculum & 5 & 5 & 10 & 20 & 30 & 30 \\
\hline $\begin{array}{l}\text { Emotionally positive beginning of a lecture, with a fun story, } \\
\text { anecdote, related to a lecture topic }\end{array}$ & 6 & 4 & 5 & 17 & 29 & 40 \\
\hline $\begin{array}{l}\text { A preliminary short test of students' knowledge of an } \\
\text { announced topic }\end{array}$ & 10 & 5 & 8 & 10 & 30 & 37 \\
\hline $\begin{array}{l}\text { Overview of a lecture topic, by providing a graphical } \\
\text { visualisation of the topic; }\end{array}$ & 1 & 1 & 6 & 17 & 36 & 51 \\
\hline $\begin{array}{l}\text { Topic outline with clear examples illustrated or by asking } \\
\text { students to provide their own examples in linking theoretical } \\
\text { knowledge with practical activity }\end{array}$ & 0 & 1 & 3 & 10 & 30 & 56 \\
\hline Variety of lecture media (other than just slide shows) & 1 & 0 & 1 & 32 & 31 & 35 \\
\hline $\begin{array}{l}\text { Conversation, discussion of key questions of the topic with } \\
\text { students }\end{array}$ & 3 & 10 & 17 & 11 & 19 & 40 \\
\hline Summarizing the topic to involve all students. & 0 & 0 & 5 & 22 & 21 & 52 \\
\hline Other & 0 & 0 & 19 & 20 & 31 & 30 \\
\hline
\end{tabular}

The majority of survey respondents fully agreed with the following statements: $56 \%(\chi 2-42.138, \mathrm{df}-1, \mathrm{p}=0.000)$ - topic outline with clear examples illustrated or by asking students to provide their own examples in linking theoretical knowledge with practical activity; $52 \%\left(\chi^{2-38.159, ~ d f-1, ~} \mathrm{p}=0.000\right)$ summarizing the topic to involve all students; $51 \%(\chi 2-45.129, \mathrm{df}-2, \mathrm{p}=0.000)$ overview of a lecture topic, by providing a graphical visualisation of the topic. The trends in this study match study results of other authors. It is argued (Eccles, 2005) that to initiate learning, students need to see and feel the value of this process and believe that the learning of a particular subject is feasible and relevantly linked to practice. The obtained results show that there is no significant difference between the assessments of students of both full-time and part-time studies, with the probability of significance under the Mann-Whitney $U$ test $\mathrm{p}>0.05$. 
Respondents expressed their agreement / disagreement with each of the below activities to support the learner's motivation to learn and its positive dynamics and assessed each statement on a six-point scale, where 1 - strongly disagree, 2 - disagree, 3 - rather disagree than agree, 4 - rather agree than disagree, 5 - agree, 6 - strongly agree (Table 5):

\section{Table 5 Subscale of student activities to support the learner's motivation to learn and its positive dynamics (percentage)}

\begin{tabular}{|c|c|c|c|c|c|c|}
\hline STATEMENT & 1 & $\begin{array}{l}2 \\
\%\end{array}$ & $\begin{array}{l}3 \\
\%\end{array}$ & $\begin{array}{l}4 \\
\%\end{array}$ & $\begin{array}{l}5 \\
\%\end{array}$ & $\begin{array}{l}6 \\
\%\end{array}$ \\
\hline $\begin{array}{l}\text { Favourable attitude to learn, to remain at peace with oneself } \\
\text { and others throughout the lecture }\end{array}$ & 1 & 2 & 5 & 12 & 25 & 56 \\
\hline Authentic student learning activities & 7 & 2 & 5 & 17 & 20 & 49 \\
\hline Activities that require cognitive commitment & 0 & 0 & 2 & 16 & 35 & 47 \\
\hline Collaboration activities & 0 & 0 & 1 & 17 & 31 & 51 \\
\hline Understanding, acceptance of rules of conduct & 0 & 0 & 10 & 30 & 29 & 31 \\
\hline Time management & 1 & 0 & 1 & 42 & 31 & 25 \\
\hline $\begin{array}{l}\text { Selection of meaningful knowledge that suggest sufficient } \\
\text { challenge for learning }\end{array}$ & 0 & 0 & 2 & 18 & 26 & 54 \\
\hline Other & 0 & 0 & 1 & 22 & 31 & 46 \\
\hline
\end{tabular}

The Mann-Whitney non-parametric criterion was used to obtain statistically significant results for student activities to support their motivation to learn. The obtained results show that there is no significant difference between the assessments of male and female, with the probability of significance under the Mann-Whitney $U$ test $p>0.05$. There was a full agreement with the following statements: $56 \%$ - favourable attitude to learn, to remain at peace with oneself and others throughout the lecture $(\chi 2-46.378, \mathrm{df}-2, \mathrm{p}=0.000) ; 54 \%$ - selection of meaningful knowledge that suggest sufficient challenge for learning $(\chi 2-46.378$, df-2, $\mathrm{p}=0.000) ; 51 \%$ - collaboration activities $(\chi 2-46.378, \mathrm{df}-2, \mathrm{p}=0.000)$. As the survey shows, respondents are willing to have not only meaningful activities but an emotionally positive learning environment, too, where they can remain at peace, that is, not in conflict, with themselves, teachers, or classmates.

\section{Discussion}

The theoretical discourse demonstrates the relevance and necessity to analyse not only learning motivation, but also motivational dynamics and competences of teachers in learning motivation, while the concept of motivation is rather suitable for action than for analysis.

Any teacher can affirm that learning motivation boosts when: learning is fun and enjoyable, a person is not tired and is capable to work, enjoys the success and 
collaboration, new learning / study material is attractive and satisfies a student's curiosity; the student feels a value of learning, gets involved in the learning and didactic process. Why is it meaningful and even necessary, for the sake of dynamics of positive motivation, to shape students' knowledge system by involving them in didactic activities adapted to a specific group? Two and a half thousand years ago, the great Chinese thinker, philosopher and teacher Confucius answered the above question by stating in his postulates, "Tell me and I will forget" (traditional class); "Show me and I may remember" (exercises, workshops, debates); "Involve me (in actual activities, real examples, processes) and I will understand" (learn, start lots of independent work, actions); "Let me out (give me power, freedom of action, space for autonomy) and I will succeed." The question is whether all modern teachers want it and capable of it? Do they have developed competencies in learning motivation? Do all teachers understand the mechanism of learning motivation?

Failure and inadequate assessments by teachers result in de-motivation and reduce a learner's willingness to learn. Therefore, knowledge of general concepts of learning motivation is not enough for a teacher - he or she has to search for ways to incorporate, maintain, and promote positive dynamics of learning motivation, i.e., to develop competencies in learning motivation.

Previous researches conducted by faculty staff of Klaipèda University revealed that university studies should focus not only on professional competencies but on the conscious and purposeful development of a student's sense of responsibility, his or her natural powers, and critical thinking, too (Jatkauskiene et al., 2015). Upon putting these key goals of higher education into practice, it is appropriate to emphasise a modern approach to learning, based on which studies are an active process of shaping a student's knowledge, understanding and personal meaning, the process of sharing one's experience and knowledge with others (Jatkauskiene et al., 2013). The above was partially supported by this research. Otherwise, the result is a loss of motivation to learn, which, in turn, leads to negative dynamics of student learning motivation.

Attitude towards learning can be classified into two groups: learning as a phenomenon to be studied at the level of individual perception (knowledge acquisition, recollection) and learning as phenomenon with a social/professional function (application, understanding, personal growth) (Keibienè et al., 2012). Yet, not every student succeeds to solve problems arising during studies. The ability of a student to learn and, at the same time, develop his or her competencies also depends on the organization in which he or she is studying, on the tools available, on the people he or she is working with, and so on. Trends within the study suggest that de-motivation is determined by inadequate student knowledge, limited time to complete assignments, extremely high demands, lack of feedback, application of assessment methods to encourage fact, formula recollection, etc. 
On the contrary, motivation is determined by didactic and learning approaches that promote active and long-term student engagement, explicit expectations, and accountability of a teacher for the quality of teaching (Daele et al., 2013, p.152). That is why teachers in higher education develop competency in learning motivation and look for certain strategies and methods to stimulate learning motivation so that to make sure a student's attitude toward learning, studies, and motivation is profound rather than superficial.

S.I. Zmejov (2010) highlighted the following competencies of the teacher in learning motivation: ability to help students to clarify existing concepts and to see other concepts of the phenomenon in question; ability to point out inconsistencies in concepts shaped by learners and consequences thereof in real life situations; to focus most intensively on the key issues that are most problematic for students; to look for ways to integrate the logistics of the study subject into its regular content. This is, however, quite difficult to put in teachers' practice in case they are not well prepared for didactic activities (Jatkauskienè et al., 2013, p.48).

Learning motivation is subject not only to the person's confidence in the value of the activity, its practical usefulness, but also to the confidence in his or her ability to engage in active learning (Fukuzawa et al., 2017, p.176). Therefore, respondents in this study pointed out an overview, outline, and summary of a lecture topic, so that to assess meeting of their expectations, the instrumentality of a teacher and their learning activities, and a meaningfulness of the lecture. If a teacher fails to provide this, dynamics of students' positive learning motivation is assumed not to be maintained. In this case, negative dynamics of motivation to learn will be observed as soon as by the middle of studies.

It is stated (Jatkauskiene et al., 2015, p.37) that as an attitude towards learning, its aims, content, technology, subject of study, etc. changes, approach to the environment in which the learning / study process takes place should change, as well. On the other hand, learning environments are increasingly argued (Bagdonas et al., 2017) to be empowering, whereby the empowerment is understood as the process of developing by people or communities of the competence to manage their own lives and decide on important matters in their lives. Thus, today's learning environment in higher education should naturally be taken care of no less than other elements of the didactic system. After all, it is one of key elements of the competency in learning motivation (Urnežienè et al., 2012). Without any support of an adequate didactic environment, students' motivation to learn will not be kept up either.

The motivation of students in higher education is not identical to that of school-children - most children and young people go to school without any motivation to learn, while those enrolled into higher education initially have quite high motivation to study. Thus, we cannot claim that faculty members and school teachers should have equal competencies to motivate learning. Competencies in 
learning motivation of teachers in higher education are based on Viau's (2009) model of learning motivation dynamics and related to their job functions: to be meaningful in the student's eyes; to be diversified in didactic methods and techniques to meet the needs, competences, personal qualities of students; to orientate didactic activity and study course content, taking into account students' skills and knowledge; to be authentic; to require the student's cognitive engagement by sharing his or her experience, knowledge, search, dissemination, commitment to knowledge, etc. All of the said competencies were verified by empirical research.

A study in Quebec involved 4,039 students and found that the students had relatively high motivation to learn during the first two semesters, whereas their learning motivation was lost or considerably dropped during the final semesters (Bedard et al., 2001, p.29). This trend clearly demonstrates the need for teachers to support and promote positive dynamics of learning motivation throughout the studies. The reasons why students lose motivation to learn were found out. Some of the participants in the research stated that their motivation to learn was lost due to too difficult and exhausting studies, various personal or financial problems, or no longer having any satisfaction or pleasure of studying. These are, though, too general reasons that cannot fully disclose the de-motivation of students during their studies. This is why we need more in-depth research, based on the learning motivation dynamics model, for not only justifying the needs of teachers for learning motivation competencies in their didactic activities, but also for the analysing of other elements of the learning motivation dynamics model (e.g., sources of motivation and activities other than discussed under this study).

\section{Conclusions}

Dynamics of learning motivation have been identified as a complex, volatile system consisting of many interacting socio-cognitive variables. The dynamics of learning motivation can be defined as a dynamic state based on the perception that a learner can have of himself and his environment that pushes him to a choice of activity, to engage in it and persevere in accomplishing in order to arrive to the goals.

Didactic activity of a teacher and his or her competencies in learning motivation have been found to be considered as sources of motivation to learn on the basis of the theoretical model of learning motivation dynamics.

The empirical research identifies factors of students' learning motivation/demotivation: didactic activity of the teachers, objective assessment of students' academic achievements, and positive learning environment. Student demotivation (loss of motivation) is determined by too difficult and problematic requirements, assignments, and content; lack of a teacher's support in learning, 
addressing learning issues; and a teacher's failure to instruct a subject in an acceptable, clear, and non-boring manner. Accordingly, the respondents point out the following components of the competency in learning motivation: didactic, psychological, social, information culture, ethical, etc.

More than half of participants of the survey believe that motivation is dynamic because of its tendency to vary (increase or decrease).

The majority of the survey participants state that the teachers' competency in learning motivation consists of the ability to give meaning to students' learning (study) and didactic activities. This matches a component of the learning motivation dynamics model (source of learning motivation), i.e., the perception of value of didactic and learning activities. As well, the respondents emphasise that knowledge and application of various didactic methods and techniques to meet students' needs, competencies, and personal characteristics is an important element of teachers' competency in learning motivation. Further, more than half of the respondents fully agree with the statement that a teacher should be able to provide students with a choice of study subjects, topics of research work, projects, team, duration of activities, method of presentation, etc. This is fully consistent with the component of the theoretical model of motivation dynamics as the source of learning motivation - the perception of controllability.

Positive learning motivation can be supported by a teacher through the following activities: topic outline with clear examples illustrated or by asking students to provide their own examples in linking theoretical knowledge with practical activity; summarizing the topic to involve all students; overview of a lecture topic, by providing a graphical visualisation of the topic.

Results of the study suggest that positive dynamics of learning motivation or keeping up of motivation is directly associated with the competencies in learning motivation possessed and demonstrated by the teacher, including the following elements: scientific, managerial, social, psychological, learning, information culture, ethical, etc. After all, there is no competency of a teacher not to influence students' learning motivation in one way or another. In other words, the study validates that one of the sources of positive dynamics in learning motivation is the perception of one's own and others' competencies.

The study finds that there is an interrelation between teachers' competencies in learning motivation and factors of students' motivation/de-motivation. Identification of the latter is important so that to establish tools for refining the objects under study (e.g., maintenance of positive dynamics of student learning motivation), to enable a purposeful action, to make a focused intervention in the ongoing teaching processes for improvement thereof and obtaining better learning outcomes for students. 


\section{References}

Bagdonas, A., \& Jankauskienè, I. (2017). Užsienio kalbų mokymosi poreikiai ir motyvacija. Mokslo taikomieji tyrimai Lietuvos kolegijose, 13, 77-85.

Bédard, D., \& Viau, R. (2001). Le profil d'apprentissage des étudiantes et des étudiants de l'Université de Sherbrooke: résultats de l'enquête menée au trimestre d'automne 2000. (p. 74). Manuscrit inédit, Université de Sherbrooke, vice-rectorat à l'enseignement.

Bédard, D. (2014). Être enseignant ou devenir enseignant dans le supérieur: telle est la question... de posture ! In G. Lameul, \& Loisy C. (Eds.), La pédagogie universitaire à l'heure du numérique (pp. 97-110). Brussels: De Boeck.

Bitinas, B. (2013). Rinktiniai edukologijos raštai. Edukologinis tyrimas: sistema ir procesas ugdymo tyrimu idejos ir problemos, 2. Vilnius: Edukologija.

Bourgeois, E. (2011). La motivation à apprendre. In E. Bourgeois, \& Chapelle G. (Eds.), Apprendre et faire apprendre, (2nd ed., pp. 235-253). Paris: Presses Universelles de France.

Daele, A., \& Sylvestre, E. (2013). Comment dynamiser un enseignement avec des grands effectifs? In Dans D. Berthiaume, \& N. Rege Colet (Eds.), La pédagogie de l'enseignement supérieur: repères théoriques et applications pratiques (pp. 149-164). Bern: Peter Lang.

Eccles, J.-S., \& Wigfield, A. (2002). Motivational beliefs, values, and goals. Annual Review of Psychology, 53(1), 109-132. DOI: 10.1146/annurev.psych.53.100901.135153

Eccles, J.-S. (2005). Subjective task value and the Eccles et al. model of achievement-related choices. In A.-J Eliot, \& C.-S. Dweck (Eds.), Handbook of competency and motivation (pp. 105-121). New York: Guilford.

Fenouillet, F., \& Lieury, A. (2013). Motivation et réussite scolaire. Paris: Dunod.

Fukuzawa, S., Boyd, C., \& Cahn, J. (2017). Student motivation in response to problem-based learning. Collected Essays on Learning and Teaching, 10, 175-188.

Jatkauskienè, B. (2013). Andragogu profesionalizacijos sistemos procesionali raiška. Monografija. Klaipèda: KU leidykla.

Jatkauskienè, B., \& Andriekienè, R.M. (2013). Universiteto dèstytojų veiklos daugiafunkcionalumas profesionalizacijos kontekste. Klaipédos universiteto atvejis. Monografija. Klaipeda: KU leidykla.

Jatkauskienė, B., Andriekienè, R.M., \& Trakšelys, K. (2015). Aukštojo mokslo didaktikos kompetencijų raiška dèstytojų veiklos kontekste. Studijos šiuolaikinëje visuomenèje. Mokslo darbai, 6(1).

Kairys, A., Liniauskaitè, A., Brazdeikienè, L., Bakševičius, L., Čepienė, R., MažeikienèGylienè, Ž., Rugevičius, M., Žakaitienè, A., \& Žakaitis, P. (2017). Studentų akademinès motyvacijos skalès (SAM-21) struktūra. Psichologija, 55, 41-55.

Keibienè, R., Jonaitienè, L., \& Daukilas, S. (2012). Studentų profesinès motyvacijos tyrimas. Sveikatos mokslai, 22(5). Retrieved from <sm-hs.eu/index.php/smhs/article/ download/365/pdf/

Matzler, J., \& Woessmann, L. (2012). The Impact of Teacher Subject Knowledge on Student Achievement: Evidence from Within-Teacher Within-Student Variation. Journal of Development Economics, 99(2), 486-496.

Ryan, R.M., \& Deci, E.L. (2000). Intrinsic and extrinsic motivations: Classic definitions and new directions. Contemporary Educational Psychology, 25, 54-67. DOI: 10.1006/ceps.1999.1020 
Proceedings of the International Scientific Conference. Volume I, May $22^{\text {th }}-23^{\text {th }}, 2020.26-44$

Schunk, D.-H., \& Parajes, F. (2002). The development of academic self-efficacy. In Dans A. Wigfield, \& J.-S. Eccles (Eds.), Development of achievement motivation (pp. 16-31). New York: Academic Press inc.

Urnežienè, E., \& Barkauskaite, M. (2012). Apie mokymosi motyvaciją kaip ugdymo proceso sẻkmès sąlygą. Retrieved 18 Dec 2019 from http://www.biblioteka.vpu.lt/pedagogika/ PDF/2012/108/urniez38-42.pdf/

Viau, R., Joly, J., \& Bédard, D. (2004). La motivation des étudiants en formation des maîtres à l'égard d'activités pédagogiques novatrices. Revue des sciences de l'éducation, 30(1) 163-176. doi: 10.7202/011775ar

Viau, R. (2014). Savoir motiver les étudiants. In Dans L. Ménard, \& L. St-Pierre (Eds.), Se former à la pédagogie de l'enseignement supérieur (pp. 235-254). Montréal: Chenelière éducation/AQPC.

Zmejov, S.I. (2010). Antropagogicheskie osnovy dejatel'nosti, kompetencij i kompetentnostej prepodavatelja vysshej shkoly v XXI veke. Vestnik MGLU, 16(595). 